\title{
The Alliance for Progress and housing policy in Rio de Janeiro and Buenos Aires in the 1960s
}

\author{
LEANDRO BENMERGUI* \\ 2115 Francis Scott Key Hall, University of Maryland, College Park, MD 20742, USA
}

\begin{abstract}
This article explores the construction of publicly financed low-income housing complexes in Rio de Janeiro, Brazil, and Buenos Aires, Argentina, in the 1960s. These housing developments were possible thanks to the arrival of foreign economic and technical assistance from the Alliance for Progress. Urban scholars, politicians, diplomats and urbanists of the Americas sought to promote middleclass habits, mass consumption and moderate political behaviour, especially among the poor, by expanding access to homeownership and 'decent' living conditions for a burgeoning urban population. As a result, the history of lowincome housing should be understood within broader transnational discourses and practices about the 'modernization' and 'development' of the urban poor.
\end{abstract}

Carlos Lacerda, the outspoken governor of the State of Guanabara, Brazil, between 1960 and 1965, used the publication of Manual of the Homeowner (1965) as the occasion to educate the new residents of Vila Kennedy, a publicly financed low-income housing complex built in the suburbs of Rio de Janeiro, about their new homes. 'Fellow Homeowner', wrote the governor to the several hundred municipal citizens who had recently been resettled from a favela (shantytown),

life was made for everyone. It is for each family to HAVE A HOME, but it is not just that. It is also for every home to HAVE A FAMILY ... It is my hope that the owner of this house, under the tutelage of God, remembers those who have not had that opportunity yet and also helps us to give it to everyone. ${ }^{1}$

In the pages that followed the governor's introductory remarks to the former favelados, the manual instructed the new residents of Vila Kennedy

\footnotetext{
* This article is part of an ongoing research agenda that speaks to processes of urbanization, urban planning and urban residential life throughout the Americas for my dissertation thesis 'Housing development: housing policy, slums, and squatter settlements in Rio de Janeiro and Buenos Aires, 1948-1973'. I much appreciate the insightful comments of Nathan Connolly, Michèle Dagenais, Philip Ethington, Paula Halperin, Bryan McCann, Jan Reiff, Mary Kay Vaughan, Daryle Williams and the anonymous referee for this special issue. While they did not necessarily agree with all the arguments presented here, their generous comments and readings of the article were invaluable.

1 Secretaria de Serviços Sociais - COHAB-GB, Manual do propirétario (Rio de Janeiro, 1965), 1; capitals in the original.
} 
in the basic domestic tasks associated with their new, modern households. The accompanying illustrations showed an immaculately dressed white woman cleaning the house, hanging out the laundry in the backyard, disposing the trash and registering their children at the local school. In the minds of the urban planners associated with the Guanabara Popular Housing Company (COHAB-GB; founded in 1960), the institution in charge of low-income housing and the co-publishers of the Manual, the resettled favelado required instruction on the proper use of their new environment. Deeply influenced by the general assumptions of the theory of modernization, the guide contrasted the domestic practices of a 'traditional' peasantry, such as food cultivation and animal rearing in close proximity to the home, with the more modern, urban domestic practices suitable for the orderly conditions of the modern home. One of the goals of the manual, in fact, was to discourage the new inhabitants from turning their backyards into farms.

Five years later in Buenos Aires, Argentina, the Municipal Housing Commission (CMV; founded in 1964) distributed To Enter into the Present, a user's guide for the low-income families relocated to the new neighbourhood of Ciudad General Belgrano. In the guide's preface, a picture of a set of keys preceded the words: 'These keys that we are giving you serve to enter into the present, this present in which every human being has the right, that of light, air, the comforts and simplicities of modern life, a home worthy of our time. ${ }^{2}$ As in the Brazilian case, an optimistic and prescriptive discourse on homeownership, space and domestic behaviour defined modern urban life.

During the 1960s, the municipal governments of Rio de Janeiro and Buenos Aires, working in concert with bilateral and multilateral development agencies based in the United States, inaugurated a number of public housing developments for low-income families. In greater Rio, these efforts included the construction of about 9,000 popular housing units in communities named Vila Kennedy, Vila Aliança, Vila Esperança and Cidade de Deus. In Buenos Aires, about 10,000 popular housing units were built during the urbanization of Parque Almirante Brown and the construction of housing complexes in Villa Lugano I-II, and Ciudad General Belgrano. These new communities of low-income city-dwellers and their built environments were made possible largely thanks to a Cold War conjuncture that channelled technical and economic assistance from the United States to Latin American public authorities as part of a larger programme for foreign aid and regional co-operation known as the Alliance for Progress, announced by United States President John F. Kennedy in March 1961. Affordable, decent housing was, in fact, one of the key targets of the multilateral plan. In this regard, housing policy became

${ }^{2}$ Comisión Municipal de la Vivienda, Para entrar en el presente (Buenos Aires: Municipalidad de la Ciudad de Buenos Aires, n.d.). 
an important aspect of inter-American relations and foreign aid during the 1960s. ${ }^{3}$

This article analyses the emergence of a new transnational modernizing sociological and urbanist discourse on the urban home during the 1960s. This discourse became an organizer of urban space and domestic life, as well as an instrument of political and social intervention that operated across national and international borders. Largely animated by the Alliance for Progress, the urbanists, diplomats, politicians and social scientists arrayed in academic institutions, international conferences, ministries of foreign relations, state planning offices and multilateral agencies formulated languages of decent housing for a burgeoning urban population. The urban housing 'problem' came to be defined as a challenge of: (a) physically building urban housing to the standards of Western capitalist democracy; (b) defining the state's role as an agent of material modernization, democratization and the social integration of the urban dweller; and (c) applying the social sciences to the technocratic administration of planned housing, redevelopment and urbanization. Within the sociological and political circuits of knowledge produced to address the Latin American path to post-war modernity, housing policy emerged as a discursive and practical antidote to underdevelopment, poverty and social instability.

If United States and Latin American urbanists shared a transnational optimism about the role that housing might play in the modernization of the so-called underdeveloped world, Brazilian and Argentine officials were particularly concerned with the displacement caused by housing policies adopted by the populist regimes of Getúlio Vargas (presidentdictator of Brazil 1930-45 and again president 1951-54) and Juan Domingo Perón (president of Argentina between 1946 and 1955). Labelling the policies of their predecessors economically irrational, deficient and demagogic, the planners of the 1960s used the multilateral appeals of expanded access to homeownership and 'decent' living conditions as means to promote middle-class habits, mass consumption and moderate political behaviour, especially among the poor. The housing component of urban planning and urban renewal thus came to be a desired outcome of modernization: an antidote to an irrational politics of working-class populism and a prophylaxis against the spectre of social upheaval and antiAmericanism that framed US-Latin American relations after the Cuban Revolution.

Within this historical conjuncture, then, the article considers public housing in Rio and Buenos Aires in its transnational, comparative and local dimensions. The analysis is animated by the new cultural approaches

${ }^{3}$ John F. Kennedy, 'Address at a White House reception for members of Congress and for the Diplomatic Corps of the Latin American republics', 13 Mar. 1961, The Department of State Bulletin, XLIV, 1136 (1961), 471-4. 
to the history of US-Latin American relations that challenge us to think about hemispheric relations in terms of 'contact zones'. A formulation first coined by Mary Louise Pratt, such zones refer to that range of networks, exchanges, borrowings, discourses, behaviours and meanings 'whereby the external became internalized in Latin America; to the way in which foreign people, ideas, commodities, and institutions have been received, contested, and appropriated'. Contact zones are sites of transculturation. As Gilbert Joseph argued, 'contact zones are not geographic places with stable significations; they may represent attempts at hegemony, but are simultaneously sites of multivocality; of negotiation, borrowing, and exchange; and of redeployment and reversal' ${ }^{4}$ I argue that public housing in Buenos Aires and Rio de Janeiro is precisely one of these zones built by multivocality, by negotiation and by unstable borrowings.

The house built via international, public financing is a contact zone par excellence. Located at the intersection of the local domesticity and transnational policies, the home is the ideal space in which to understand a series of expectations, ideas and discourses about family, customs, social behaviour, intimacy and material wealth. Within discourses of modernization and development, the house became not only the locus of improved living conditions for the urban poor, but also, as part of the modern built environment, became an agent of cultural transformation. However, the notions attached to the new spatial arrangement and living conditions were not imposed externally; they were the outcome of the exchange and negotiation of widely circulated meanings, circumscribed by local and national conditions.

The selection of Rio de Janeiro and Buenos Aires allows the historian to study similar projects in rather dissimilar national and local contexts where the degree of conflict varied according to the local political circumstances, the different dimensions of poverty and the balance of power among different actors. Yet despite these differences, both cities undertook urban reform and housing projects in the 1960s and received financial and technical aid from the United States for the first time. Interestingly, the notions of modernity that shaped these plans shared a similar vision of the role of housing in modernizing people's lives. Finally, the inter-American connection to these projects - all counted upon bilateral and multilateral technical assistance and direct aid from the United States and the InterAmerican Development Bank, among others - provides direct insight into the actual operation of circuits of knowledge and their practical outcomes in the built environment.

${ }^{4}$ Gilbert Joseph, Catherine Legrand and Ricardo Salvatore (eds.), Close Encounter of Empire: Writing the Cultural History of U.S.-Latin American Relations (Durham and London, 1998), 5. See also Mary Louise Pratt, Imperial Eyes: Travel, Writing and Transculturation (London and New York, 1992); Gilbert Joseph and Daniela Spenser, In from the Cold: Latin America's New Encounter with the Cold War (Durham and London, 2008). 


\section{The housing problem in the era of modernization and developmentalism}

At the dawn of the post-war era, the question of housing the poor was hardly new for city planners in Buenos Aires and Rio de Janeiro. Since the late nineteenth century, local governments, social reformers and hygienists in the two South American capital cities had treated nascent clusters of tenements and shantytowns as sites of disease and moral decay. Governmental response was limited but the problem of housing the poor came to be a concern of public administration. Both cities grew outward from the centre to the suburbs, incorporating new areas, developing commuter transportation and ultimately consolidating the expanded urban network. Expansion, however, followed geographical factors that determined the different pattern of settlement of favelas and villas miseria (Argentine popular term for shantytowns). While Buenos Aires is located in a relatively flat, low-lying area that allowed horizontal expansion without major natural obstacles, Rio's topography includes massifs, crests and scattered hills, bays, rivers, a lake and ocean beaches. The massif Tijuca physically divides the city in two north-south zones. It occupies 95 square kilometres, with hundreds of smaller hills and forests. In the history of favelas, those facts are very important because those were the places where irregular settlements were established, vertically distant from the urbanized city grid but relatively near in terms of horizontal distance to workplaces.

By the mid-1930s and during World War II population growth accelerated in Buenos Aires and Rio when both cities led the process of import-substitution industrialization - the state-induced industrialization designed to reduce foreign dependency on importation in the context of global depression and war. By the post-war period, the stagnation of traditional rural production, the attendant broad-scale rural-to-urban migration and the improvement of mortality rates contributed to a spectacular demographic boom, an alarming increase in housing shortages and the concomitant expansion of illegal settlements. In the 1940s and early 1950s, the municipal administrations of Buenos Aires and Rio, working in conjunction with the federal government of Perón and Vargas, began to adopt a more vigorous approach towards publicly financed affordable housing, empowered by the political and social mobilization of the Buenos Aires and Rio's working class. ${ }^{5}$

${ }^{5}$ See among others, Oscar Yujnovsky, Claves politicas del problema habitacional argentine 19551981 (Buenos Aires, 1984); Anahi Ballent, Las huellas de la politica: vivienda, ciudad, Peronismo en Buenos Aires, 1943-1955 (Bernal, 2005); Mark Healy, 'The ruins of the new Argentina: Peronism, architecture, and the remaking of San Juan after the 1944 earthquake' (Duke University Ph.D. Thesis, 2000); Rosa Aboy, Viviendas para el pueblo: espacio urbano y sociabilidad en el barrio Los Perales, 1946-1955 (Buenos Aires, 2005); Licia do Prado Valladares, A invenção da favela. Do mito de origem a favela.com (Rio de Janeiro, 2005); Alba Zaluar and Marcos Alvito, Um século de favela (Rio de Janeiro, 1998); Lilian Fessler Vaz, Modernidade e moradia: habitação 
Post-war economic fluctuation and political instability hampered effective urban planning, exacerbating a difficult situation in which the demands of a growing population overwhelmed not merely the state's capacity to house the poor but the entire city's capacity to provide such basic services as water and sewage, health and education, and traffic engineering to all city residents, regardless of income. The inadequacies of the urban infrastructure, in conjunction with the poverty of many urban dwellers, continued and were aggravated by a near threefold increase in the number of people living in Rio's favelas between 1950 and 1970. By 1960, almost 10 per cent of Rio's total population was living in shantytowns. ${ }^{6}$ In addition, the construction of tunnels, overpasses, the extension of the sewage and water system as well as the eradication of slums contributed to the densification of Rio's South Zone in the 1950s. There wealthy cariocas (demonym for Rio's residents) arrived at the neighbourhoods of Ipanema, Leblon and Gávea. Meanwhile, new favelas loomed in the hills of the South Zone as their inhabitants provided a cheap labour force for construction and domestic work. In Buenos Aires, the population of the villas miserias remained smaller, reaching just 2 per cent of the overall population of the Buenos Aires Metropolitan Region (AMBA), although the absolute numbers were becoming impressive: the squatter population peaked in the late 1960 s at over a half million residents.

The problems associated with rapid urbanization were a global phenomenon of the period. In 1969, the Economic Council of Latin America (ECLA) found that the increase of the urban population rate was 55 per cent between 1950 and 1960 - with many large cities growing 6 to 7 per cent annually, while the rural population rose only 12 per cent for that entire period. ${ }^{8}$ Yet structural economic factors and political instability restrained economic growth, creating an awkward situation in which the economy could not absorb the rapidly increasing supply of workers. Poverty and inadequate housing thus became one of the most striking features of the post-war Latin American city.

In that scenario, sociologists, urban scholars, city planners, architects, politicians and policymakers of the Americas, as well as multinational

coletiva no Rio de Janeiro séculos XIX e XX (Rio de Janerio, 2002); Brodwyn Fischer, A Poverty of Rights: Citizenship and Inequality in Twentieth-Century Rio de Janerio (Stanford, 2008).

${ }^{6}$ Rio's urban population almost doubled between 1950 and 1970, reaching highest historical rates. Favelado population was 169,000 in 1950; 335,000 in 1960; and 554,000 in 1970. See, e.g., Lucien Parisse, Favelas do Rio de Janeiro: evolução e sentido (Rio de Janeiro, 1969), 145; Janice Perlman, The Myth of Marginality: Poverty and Politics in Rio de Janeiro (Berkeley, 1976), 14.

7 By 1947, AMBA concentrated almost half of the population of the country. In the lapse of 20 years the population almost doubled from 6,730,000 in 1947 to 11,434,000 in 1970. ECLA's Boletín demográfico. Edición especial. Urbanización y evolución de la población urbana de América Latina (1950 -1990); Horacio Torres, 'El mapa social de Buenos Aires en 1943, 1947 y 1960. Buenos Aires y los modelos urbanos', Desarrollo económico, 19 (1978), 163-204; Yujnovsky, Claves politicas del problema habitacional argentino, 1955-1981, 249.

${ }^{8}$ United Nations Economic Commission for Latin America. Social Change and Social Development Policy in Latin America, 1969, 34, cited in Jerome Levinson and Juan de Onís, The Alliance that Lost its Way: A Critical Report on the Alliance for Progress (Chicago, 1970). 
organisms, lending agencies and philanthropic foundations, all sought to understand and explain the structural changes that were occurring in the region in order more effectively to act upon them. Argentine urban historian Adrián Gorelik pointed out that between the 1950s and 1970s 'the Latin American City' emerged as a trope, a cultural artifact and a figure of the intellectual political imagination of the region. ${ }^{9}$ The proliferation of research centres and the emergence of multiple networks where scholars, political elites and international organizations interacted in conferences, symposiums and collaborative research projects became the 'contact zones' where the urban housing problem became an object of transnational concern.

Modernization theory provided scientific and ideological rationale for the model of social transformation shared by these actors. Resting upon Max Weber's understanding of the 'rationalization' process, they recognized modernization as a process that implied urbanization, universalization, technological expansion, bureaucratization and rationalization of state procedures in economy and society - a rationalization that might produce a whole transformation in people's everyday lives. ${ }^{10}$ Therefore, societies were expected to become more rational and less emotional, they would be moderated in politics while state proceedings would be performed by an elite comprised of technocrats and politicians instead of irrational and populist leaders and the populace would incorporate the habits of mass consumption associated with a middle-class society.

These notions came to be the core of US foreign policy in the Kennedy and Lyndon B. Johnson administrations, underlying the Alliance for Progress in particular. They offered not only the scientific explanation of the structural changes occurring in the post-war world but also the ideological legitimization of the expansive role of the United States in the new geopolitical scenario. Within Cold War anxieties revealed by the Cuban Revolution and the process of decolonization in Africa and Asia, the Alliance for Progress was the mechanism to promote peaceful social reform to counter the perceived communist threat. President Kennedy himself viewed Latin America as a hot spot of Cold War politics and launched his programme of economic co-operation by promising the disbursement of $\$ 20$ billion within a decade. Latin American countries received US dollars and technical assistance designated for land reform, health, education and housing projects.

9 Adrián Gorelik, 'A produção da cidade latino-americana', Tempo social, revista de sociologia da USP , 17 (2005), 111-33. See also Diane Davis, 'Cities in global context: a brief intellectual history', International Journal of Urban and Regional Research, 29 (2005), 92-109; and Richard Harris and Ceinwen Giles, 'A mixed message: the agents and forms of international housing policy, 1945-1973', Habitat International, 27 (2003), 167-91.

10 Michael Latham, Modernization as Ideology: American Social Science and 'Nation Building' in the Kennedy Era (Chapel Hill, 2000); Nils Gilman, Mandarins of the Future: Modernization Theory in Cold War America (Baltimore, 2003); Arturo Escobar, Encountering Development: The Making and Unmaking of the Third World (New Jersey, 1995). 
In The Stages of Economic Growth (1960), a book that became a paramount work of modernization theory, W.W. Rostow synthesized the role of the United States in the 'free world': specifically, in assisting developing countries with their economic 'take-off' and in promoting development through self-sustaining economic growth and industrialization. ${ }^{11}$ That assistance was almost considered a mission by US technocrats. Teodoro Moscoso, the US co-ordinator of the Alliance for Progress directly appointed by President Kennedy, declared in 1961, 'we must convince these [Latin American] peoples that through the Alliance they can really reach progress and happiness... We must evangelize them! ... you must remember, this job is not just the administration of billions of dollars. It is a job of evangelizing' (my emphasis). ${ }^{12}$ Interestingly, Moscoso's previous credentials were his experience in Puerto Rico as the ideologue and head of the 'Operation Bootstrap', a plan for industrializing the island that was seen as the exemplar of how a poor country could progress economically. Programmes that included urbanization and housing development plans became one of the cornerstones for US foreign policy in Latin America, even when they failed in the long term to achieve their original goals. ${ }^{13}$

Modernization theory therefore shaped the language of US foreign policy and scholarship towards Latin America. But even when modernization theorists such as Talcott Parsons, W.W. Rostow or Lucien Pye were most prominent among Latin American scholars, their influence did not grow in an intellectual vacuum. For instance, the United Nations Economic Commission for Latin America (ECLA/CEPAL), founded in 1948, elaborated an indigenous Latin American model of development denominated desarrollismo (developmentalism) that proclaimed the modernization of the society and economy through an agenda of economic growth, heavy industrialization, administrative reform and expanded capital accumulation. Its analytical foundations took into consideration the structural social and economic situation of the region in a historical perspective that included the legacy of the colonial tie with Spain, the role of regional oligarchies and the emergence of populism.

Sociologists like Gino Germani in Argentina introduced modern sociology into Latin American universities and followed the methodology of modernization theory in order to study the migratory process of vast contingents of the rural population to the cities. Germani was an exile from Mussolini's Italy and founded the School of Sociology at the University of Buenos Aires in 1955, after the ousting of President Perón. His work focused on the explanation of the mobilizing power that Perón, a 'charismatic leader' like Mussolini according to Germani, had among Argentine popular classes. The answer was in the fact that in the

11 W.W. Rostow, The Stages of Economic Growth: A Non-Communist Manifesto (Cambridge, 1960), 4-16.

12 Tad Szulc, 'Selling a revolution to Latin America', New York Times, 17 December 1961, 10.

13 On Moscoso and the 'Operation Bootstrap', see A.W. Maldonado, Teodoro Moscoso and Puerto Rico's Operation Bootstrap (Gainesville, 1997). 
1940s, recently arrived rural migrants in Buenos Aires kept their rural habits, which were characterized by emotion, localism and attachment to kinship ties. This lack of modernization and urbanization among rural newcomers allowed Perón to connect with their emotional/irrational side. Significantly, Germani conducted his field research work in a shantytown in the industrial area of Buenos Aires, comparing the newly arrived population to that which had been established in the area for a generation or so and which had achieved a higher standard of housing.

In 1959, Philip Hauser, director of the Population Research and Training Centre at the University of Chicago, and also the chair of the Social Science Research Council Committee on Urbanization, an institution founded in 1958 to study the process of urbanization in developing countries, organized a seminar on urbanization problems in Latin America in Santiago, Chile. Sponsored by UNESCO, the UN/Bureau of Social Affairs and ECLA/CEPAL in co-operation with the International Labor Organization and the Organization of American States, the seminar became an important space in which Latin American scholars and policymakers met their American counterparts. There, key figures of urban scholarship of the Americas such as Gino Germani, Juarez Rubens Brandão Lopes, José Matos Mar and Andrew Pearse, debated the ongoing field research they had conducted in slums and shantytowns of Buenos Aires, São Paulo, Lima and Rio de Janeiro. ${ }^{14}$ They discussed such issues as the demographic aspects of urbanization, the social and economic structure, the relationship between migration and urbanization and between economic development, industrialization and the growth of urban population.

Therefore, institutions like ECLA and scholars like Germani framed their language within the notions of modernization theory. This fact, however, did not imply literal translation but selective appropriation. It was through the circulation of scholars and specialists in conferences, such as the one in Chile in 1959, where these notions were borrowed, disputed and negotiated. These 'encounters' provided the space in which transnational actors and institutions adopted a modernizing interpretation of urban transformations that, in turn, shaped interventions into the urban fabric. If the urban space was considered the locus of modernity and an agent of social and cultural change, the urban house was the most basic spatial unit in which that transformation might operate. The construction of public housing by the municipal and national governments of Rio de Janeiro and Buenos Aires (with the financial and technical aid of foreign institutions) took effect within these broader notions built transnationally.

14 Philip Hauser (ed.),Urbanization in Latin America: Proceedings of a Seminar on Urbanization Problems in Latin America (New York, 1961). 


\section{The local, the national and the transnational dimension of popular housing}

The federal and municipal administrations that followed the end of the populist regimes of Perón, ousted in a coup in 1955, and Vargas, who committed suicide in 1954, embarked on the set of economic ideas and practices animated by the theory of developmentalism, in order to transcend the populist past. ${ }^{15}$ In the field of housing, the post-Perón/post-Vargas governments of the mid-1950s and early 1960s began to mobilize domestic capital following international guidelines to finance the construction of middle-class dwellings. They created saving and loan companies and the rationalization of the National Mortgage Bank in 1957 (Banco Hipotecario Nacional) in Argentina and the National Housing Banks (Banco Nacional de Habitação) in Brazil created in 1964. Gains in low-income housing fared poorly in comparison, as private real-estate investors and the construction industry found few incentives to embrace popular housing.

The Inter-American Development Bank (IDB), founded in 1959 as part of the demands made by Latin American countries to foster hemispheric co-operation, and the Alliance for Progress, announced in 1961, changed the equation, facilitating the availability of financial resources for comprehensive planning instead of the project orientation approach of previous experiences. ${ }^{16}$ The IDB became the administrative agency in the implementation of three different types of help: (a) selfhelp housing; (b) aid to savings and loan associations; and (c) loans to public housing authorities. In addition, the 1961 US Foreign Assistance Act reorganized the foreign assistance programme, creating the US Agency for International Development (USAID), as the central agency for longterm economic and social development assistance. USAID established a Housing Guaranty Programme to stimulate US private investment in housing and to use funds generated from the surplus of US agricultural exports financed by Public Law 480 Funds for Latin American Housing, including the Guanabara Housing Programme. ${ }^{17}$ Further, US public and private investors also attempted directly to finance or build housing in Latin America, although economic instability and high inflation discouraged such adventures. ${ }^{18}$

15 See Kathryn Sikkink, Ideas and Institutions: Developmentalism in Brazil and Argentina (Ithaca and London, 1991); Carlos Altamirano, 'Desarrollo y desarrollistas', Prismas, Revista de historia intelectual, 2 (1998), 75-94.

16 Thomas Zoumaras, 'Containing Castro: promoting homeownership in Peru, 1956-61', Diplomatic History, 10 (1986), 178-9.

17 See Sean Elliott, Financing Latin American Housing: Domestic Savings Mobilization and U.S. Assistance Policy (New York, 1968); Godwin Arku and Richard Harris, 'Housing as a tool of economic development since 1929', International Journal of Urban and Regional Research, 29 (2005), 895-915; and Harris and Giles, 'A mixed message'.

18 The Housing and Home Finance Agency, the Savings and Loan Association, the Rockefeller's International Basic Economy Corporation and even the AFL-CIO were among the most important American institutions interested in housing in Latin America. 
When the right-of-centre journalist Carlos Lacerda became the first governor of the state of Guanabara (1960-65), as Rio came to be known after the transfer of the capital to Brasilia, he framed his administration as a rupture with past practices associated with populism, personalism, corruption and lack of administrative perspective, on the one hand, and as a deliverer of urban reform, on the other. Lacerda's renowned role in the opposition to the Vargas regime and his well-known sympathies to the US made him a model Cold War politician in a Third World city for the Kennedy administration. ${ }^{19}$

From the beginning, Lacerda adopted a new model of political and administrative style that emphasized 'modern', 'efficient' and rational management to achieve a more dynamic and executive bureaucratic apparatus designed to accomplish his ambitious programme of urban renewal. He decentralized local administration to guarantee organizational autonomy in the decision-making process and created autarchic agencies charged with urban renewal. During his term, Cariocas oversaw the expansion of the water and sewage system, and the construction of schools and basic urban infrastructure such as tunnels, expressways and overpasses that solved the obstacles of Rio's topography. ${ }^{20}$ Under Lacerda, the state-sponsored COHAB-GB, founded 1962, the municipal Secretariat of Social Services and the Catholic Church's Fundação Leão XIII - (under governmental control since 1962) joined forces to co-ordinate plans for slum eradication, low-income housing and the extension of social services to the urban poor. In the first two years, Lacerda collaborated with favelas' neighbourhood associations to establish community development plans to cope with such urgent demands as trash collection and the installation of power lines. By 1962, however, the governor turned to a more systematic approach of slum clearance and resident relocation involving the use of police force and the bulldozing of shacks. This change was related to a generalized perception among middle-upper-class cariocas that favelas were sites of marginality and urban squalor, an obstacle to large-scale real-estate interests and an uncomfortable presence in Rio's cityscape. The identification of poor living conditions with marginality and criminality, rather than as the outcome of more structural economic factors, created the idea that relocating favelados in new housing complexes might bring them into a situation of formality.

19 John W. F. Dulles, Carlos Lacerda, Brazilian Crusader (Austin, 1991); Bryan McCann, 'Carlos Lacerda: the rise and fall of a middle-class populist in 1950s Brazil', Hispanic American Historical Review, 83 (2003), 661-96.

20 Marly Silva da Motta, Rio de Janeiro: de cidade-capital a Estado da Guanabara (Rio de Janeiro, 2001); Angela Moulin S. Penalva Santos, Economia, espaço e sociedade no Rio de Janeiro (Rio de Janeiro, 2003); Mark Kehren, 'Tunnel vision: urban renewal in Rio de Janeiro, 19601975', University of Maryland Ph.D. thesis, 2006; Mauricio Perez Dominguez, Lacerda na Guanabara: a reconstrução do Rio de Janeiro nos anos 1960 (Rio de Janeiro, 2008). 
Slum clearance and low-income housing construction was thus an integral part of Lacerda's broader plan of urban renewal. ${ }^{21}$

The governor's credentials as a politician hostile to the heterodoxy of populism and the orthodoxy of the left, yet still committed to certain aspects of social reform, placed him in good stead with the Kennedy administration. Seeking to bolster Lacerda's national visibility and popularity, American assistance for urban programmes was offered directly to the local government of Guanabara, bypassing a federal government run by numerous sworn enemies of Lacerda, including President João Goulart. So, between 1962 and 1965, USAID provided three different loans, totalling almost the equivalent of $\$ 4.5$ million, to COHABGB for costs associated with the construction of a handful of housing complexes in Rio's periphery: Vila Aliança in Bangú (2,183 units), Vila Esperança (464 units) in Vigario Geral, Vila Kennedy in Senador Camará and Cidade de Deus (City of God) in Jacarepaguá.

Vila Kennedy was the most ambitious of the Brazilian housing development projects co-funded by United States aid. The government of Guanabara bought low-cost land for the urbanization and building of Vila Kennedy, close to Santa Cruz and 30 miles west of the city centre. ${ }^{22}$ The construction of affordable single-family homes in such a massive way allowed the rationalization of the construction process, which cheapened costs. The spatial design emphasized long street corridors in which long rows of houses created a sense of repetition. The conception behind the different floor plans was the embryo-house (single room, kitchen and bathroom), allowing the homeowner to add to it whenever he was able to afford materials and time. It was also to be a model for a new kind of public housing, in which a large-scale popular housing development would be granted all the amenities of the modern urban home while enjoying proximity to a planned new industrial zone. The idea, then, was to build a self-contained residential neighbourhood for the future labour force of the industries of Santa Cruz.

The actual construction and occupation of Vila Kennedy failed to meet this lofty goal. As the new housing development emerged in a flat area in the Western Zone of the city, the planned industrial park in Santa Cruz

21 The bibliography on favelas is vast; among the classics see Anthony Leeds and Elizabeth Leeds, A sociologia do Brasil urbano (Rio de Janeiro, 1978); Mauricio Abreu, Evolução urbana do Rio de Janeiro (Rio de Janeiro, 1987); Parisse, Favelas do Rio de Janeiro; Perlman, The Myth of Marginality; Victor V. Valla, Educação e favela: políticas para as favelas do Rio de Janeiro, 19401985 (Petrópolis, 1986); Licia do Prado Valladares, Passa-se uma casa: análise do programa de remoção de favelas do Rio de Janeiro (Rio de Janeiro, 1978); Zaluar and Alvito, Um século de favela; Américo Freire e Lúcia Lippi Oliveira (eds.), Capítulos da memória do urbanismo carioca: depoimentos ao CPDOC/FGV (Rio de Janeiro, 2002).

22 The Progress of Guanabara State Company was the agency in charge of promoting industrial development in the state, inspired by the Puerto Rican Industrial Development Company. The original plan included the construction of a steel industry in Santa Cruz. Clemente Mariani's collection, CMa ae COPEG 1960.12.29; Centro de Pesquisa e Documentação de História Contemporânea do Brasil (CPDOC). 


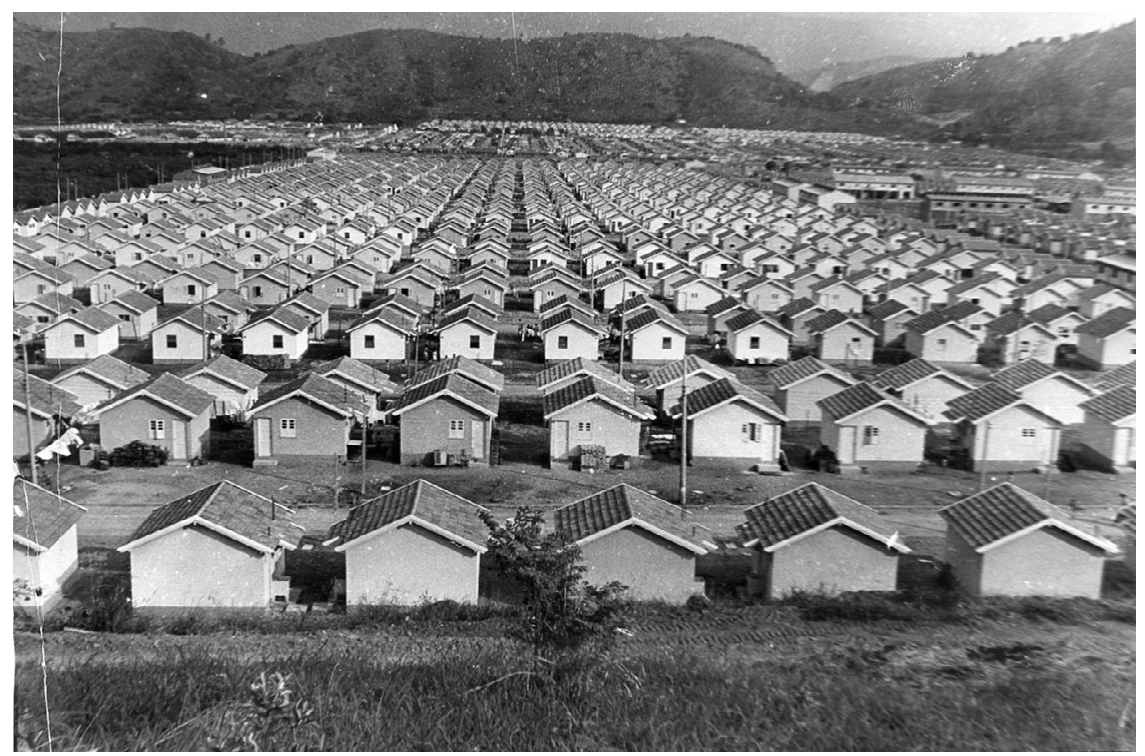

Figure 1: Vila Kennedy, Rio de Janeiro, c. 1965. The State of Guanabara built this housing development with the economic and technical assistance of the US Agency for International Development (AID) in the context of the Alliance for Progress. COHAB-GB, A COHAB através de números e imagens (Rio de Janeiro, 1965).

failed to materialize. Transportation services to other parts of the city remained notoriously poor. At the same time, the areas in central Rio that experienced slum eradication fell under the gaze of large-scale real-estate interests, including the Hilton Hotel Corporation, who agreed to pay $\$ 8$ million to Guanabara State for rights to construct a 350-room hotel tower on the Morro do Pasmado, overlooking scenic Guanabara Bay. ${ }^{23}$

Despite the missed objectives, Lacerda still treated the new housing complexes and the eradication of favelas as prominent examples of good governance. American and Rio government officials often accompanied the governor during his publicized visits to the favelas facing eradication as well as to the new modern homes. On 18 August 1962, for example, Lacerda escorted Teodoro Moscoso, and Lincoln Gordon, US ambassador to Brazil, to the favela of Bom Jesús, whose population was undergoing resettlement in Vila Aliança. The host introduced the American representatives as 'friends of Brazil', leaders of a programme 'to help those who help

${ }^{23}$ Local and international criticism on the construction of Vila Kennedy began shortly after its inauguration and included USAID consultants and US Senator Fullbright. See Lawrence Salmen, 'Housing alternatives for the carioca working class: a comparison between favelas and casas de comodos', América Latina, 13 (1970), 51-70; Bernard Wagner, David McVoy and Gordon Edwards, 'Guanabara housing and urban development program', AID Housing and Urban Development Team, 1966, mimeo. 
themselves'. Later that day in Vila Aliança, Moscoso delivered a speech, covered by the American press, that celebrated the fact that the newcomers were going to 'assume new responsibilities', becoming homeowners rather than illegal squatters. Favelado residents, however, reacted against Moscoso, complaining, 'We never received any help, the state did not send a teacher or a doctor', and claiming that it had always been the neighbourhood association that had cared about them rather than the government. Moscoso dismissed the charge, averring that people always complained in those cases; it had happened to him during the execution of his urban renewal and slum clearance plans in Puerto Rico as well. ${ }^{24}$

The presence of US officials linked with the Alliance for Progress in Vila Kennedy and Vila Aliança thus indicates that these housing programmes were part of an interconnected web of specific local, national and transnational interests and representations about urban poverty in the Americas in the 1960s rather than mere local interventions into the urban fabric. It is precisely in this dimension that we can bring similar housing programmes in Buenos Aires into the analysis.

As early as 1948, several of the key problems of Buenos Aires had been identified in El estudio para el Plan de Buenos Aires (EPBA), a document drafted by a group of modernist architects who had been working with Le Corbusier. Problems identified in the EPBA included excessive concentration of commercial, residential and industrial functions in the city's downtown, a lack of adequate zoning, the overwhelming demographic imbalance between North and South Buenos Aires, a deficient traffic system, scarce green and recreational areas and a general housing shortage. ${ }^{25}$

Animated by the problems identified in the EPBA, Buenos Aires mayor Horacio Giralt commissioned the Organización del Plan Regulador in late 1957. The plan innovated in redefining the urban space at three different levels: the city in itself, the metropolitan district within a range of 30 kilometres, and the regional area within a range of 100 kilometres. In addition, the plan sought to establish a series of hierarchies in the planning agenda that included long-term reforms as well as programmes of immediate impact. With the support of the developmentalist administration of President Frondizi (1958-62) a master plan for the city was released in 1962. One of the most ambitious programmes of the master plan was the incorporation and urbanization of a vast area of approximately 1,434 hectares (3,543 acres), equal to 9 per cent of the city's total surface, located in the south-western corner of Buenos Aires, which was still a relatively depopulated swampland. Known as the Bañado de Flores, the region

24 'Brazilian wary on aid benefits', New York Times, 19 Aug. 1962, 31.

25 Anahí Ballent described the history of the EPBA as the 'brief era of urban planning from 1946 to 1949', Ballent, Las huellas de la politica, 213. On the plan, see also Odilia Suárez, Planes y códigos para Buenos Aires 1925-1985 (Buenos Aires, 1986), 15. On the history and debates about modernist architecture in Argentina see Jorge Francisco Liernur, 'El discreto encanto de nuestra arquitectura, 1930/1960', Summa Revista de Arquitectura, 223 (1986), 60-79; and Healy, 'The ruins of the new Argentina'. 
was an inhospitable low-lying area often flooded by the waters of the Matanza River and its tributaries. There, poor people managed to build shacks and took advantage of the relatively proximity to working sites. The incorporation and urbanization of the area demanded the federal and local government become involved with local planning through the creation and execution of urban renewal legislation and the institutionalization of the bureaucratic and technical apparatus in charge of urban reform and housing construction, in the form of the CMV. ${ }^{26}$

Short-term plans in the area of housing underlined the promotion of urban rehabilitation of those terrains in which present-day use is inadequate to the level of development reached by the city' and specified the urbanization of residential and recreational zones in the city's south. ${ }^{27}$ The development of this area, which became known as Centro Urbano Integrado Parque Almirante Brown (PAB), was the most important programme of urban renewal in terms of dimensions, social implications, applied organizational and technical skills and capital investment. ${ }^{28}$ Presidential Decree 8717 of 1962 authorized the definitive urbanization of the Parque, envisioning a large-scale, multiyear programme of public works that included flood control and the construction of artificial lakes and recreational areas. The Municipality of Buenos Aires assumed technical and financial control of the basic infrastructure and the CMV became the overarching institution in charge of the co-ordination of the different operations. The Inter-American Development Bank supplied funds for feasibility studies and for the construction of the housing complexes in the area. This study was conducted by a group of foreign experts, including a sociological survey of the slums of the area directed by L. Albert Wilson, consultant of the Foundation for Co-operative Housing, and employee of USAID. ${ }^{29}$

When the mayor of Buenos Aires at that time, Francisco Rabanal, turned to the IDB with a loan request in December 1965, the preparations

26 The first legislation to regulate the Bañado de Flores dated back to 1907. There were few plans for the sanitation and urbanization of the area: González Maseda's Gran Parque del Sud, 1936, and Ítala Fulva Villa and Horacio Nazar's Barrio Parque de los Trabajadores in 1944. With differences both plans sought the articulation of industrial and low-income residential areas. See Graciela Silvestri, El color del río: historia cultural del paisaje del Riachuelo (Bernal, 2003), 143-9.

27 Organización del Plan Regulador, Descripción sintética del plan regulador (Buenos Aires, 1968), 56.

28 Besides the Parque Almirante Brown, the plan indicated the creation of residential areas in 'Casa Amarilla' (23.5 ha.; 23,500 inhabitants) and 'Catalinas Sur' (8.5 ha.; 8,900 inhabitants) in the neighbourhood of La Boca; the ex-Arsenal 'Esteban de Luca' (20 ha.; 20,000 inhabitants); the ex-National Penitentiary (10 ha.; 17,200 inhabitants) in the neighbourhood of Palermo; 'Catalinas Norte' (offices, hotels, shopping areas and parking lots) in Retiro; the terrains of the College of Agronomy-University of Buenos Aires (40,000 inhabitants); 'Playa Caballito' (26 ha.) and the Parque Almirante Brown (1,400 ha.; 250,000 inhabitants); Plano Director del Plan Regulador, 3-4.

${ }^{29}$ L. Albert Wilson, Voice of the Villas: Socio-Economic Analysis of the Residents of the Villas in Parque Almirante Brown, Buenos Aires, Argentina, FCH, Company and Foundation for Co-operative Housing Inc., 1965. 


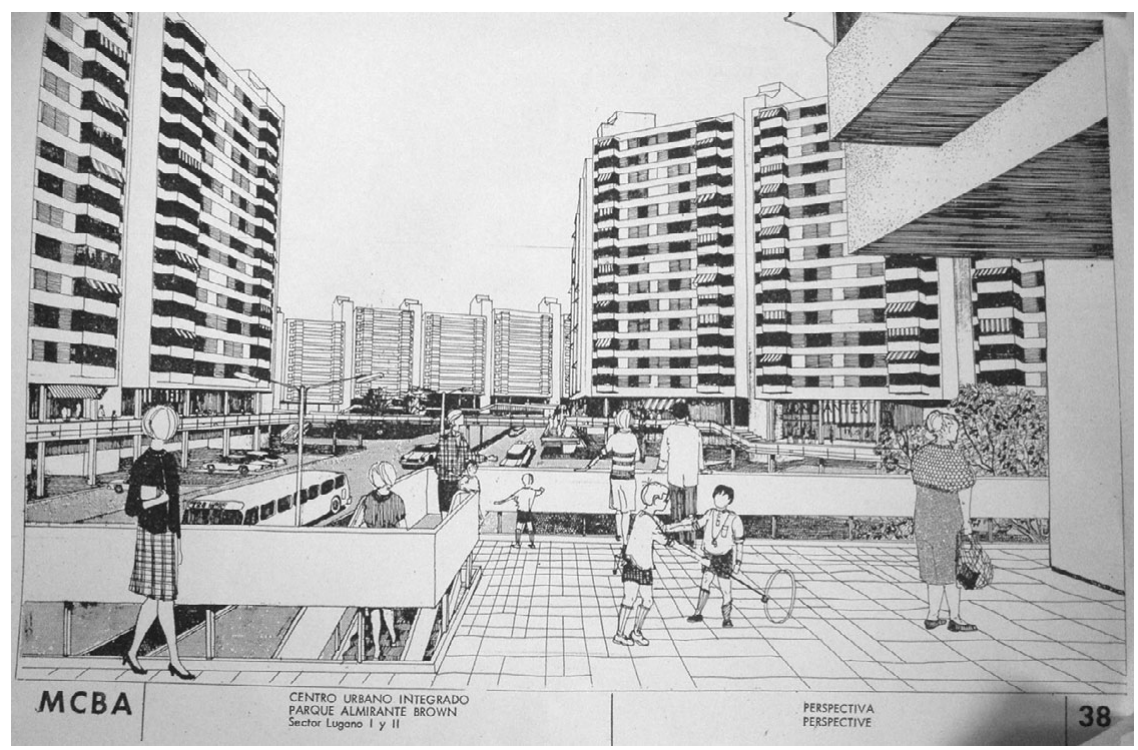

Figure 2: Centro Urban Integrado Parque Almirante Brown, Sector Lugano I and II, Buenos Aires, 1965. The construction of Villa Lugano I and II was financially possible thanks to the assistance of the Inter-American Development Bank during the Alliance for Progress. The official drawings from the Buenos Aires Municipal Housing Commission envisioned a modern, white, middle-class urban dweller living in a sanitized space. Municipalidad de la Ciudad de Buenos Aires, Solicitud de préstamo al Banco Interamericano de desarrollo (Buenos Aires, 1965).

for urbanization in Parque Almirante Brown were proceeding at steady pace. The request established the construction of two residential neighbourhoods, Villa Lugano I-II and Villa Soldati, for working families that could afford monthly installments. To be built in stages, the original plan envisioned the building of 50,000 housing units to accommodate 250,000 people. The loan proposal applied to the first stage: the construction of 6,440 multifamily units in Villa Lugano, the eradication of four little Villas de Emergencia, as well as the construction of 3,024 single-family houses in Ciudad General Belgrano in Greater Buenos Aires, for the people removed from the slums. For this latter development, the Municipality of Buenos Aires bought an area of 90 hectares (222 acres) in Greater Buenos Aires, 6 kilometres from PAB. ${ }^{30}$ Conceived as neighbourhood units, the plan was to build well-planned and selfcontained integrated urban centres provided with collective services

${ }^{30}$ See Andrea Catenazzi and Teresa Boselli, 'Los arquitectos proyectistas y las politicas oficiales de vivienda - Area Metropolitana de Buenos Aires, 1963/1973', Revista AREA, 5 (1999), 35-53. 


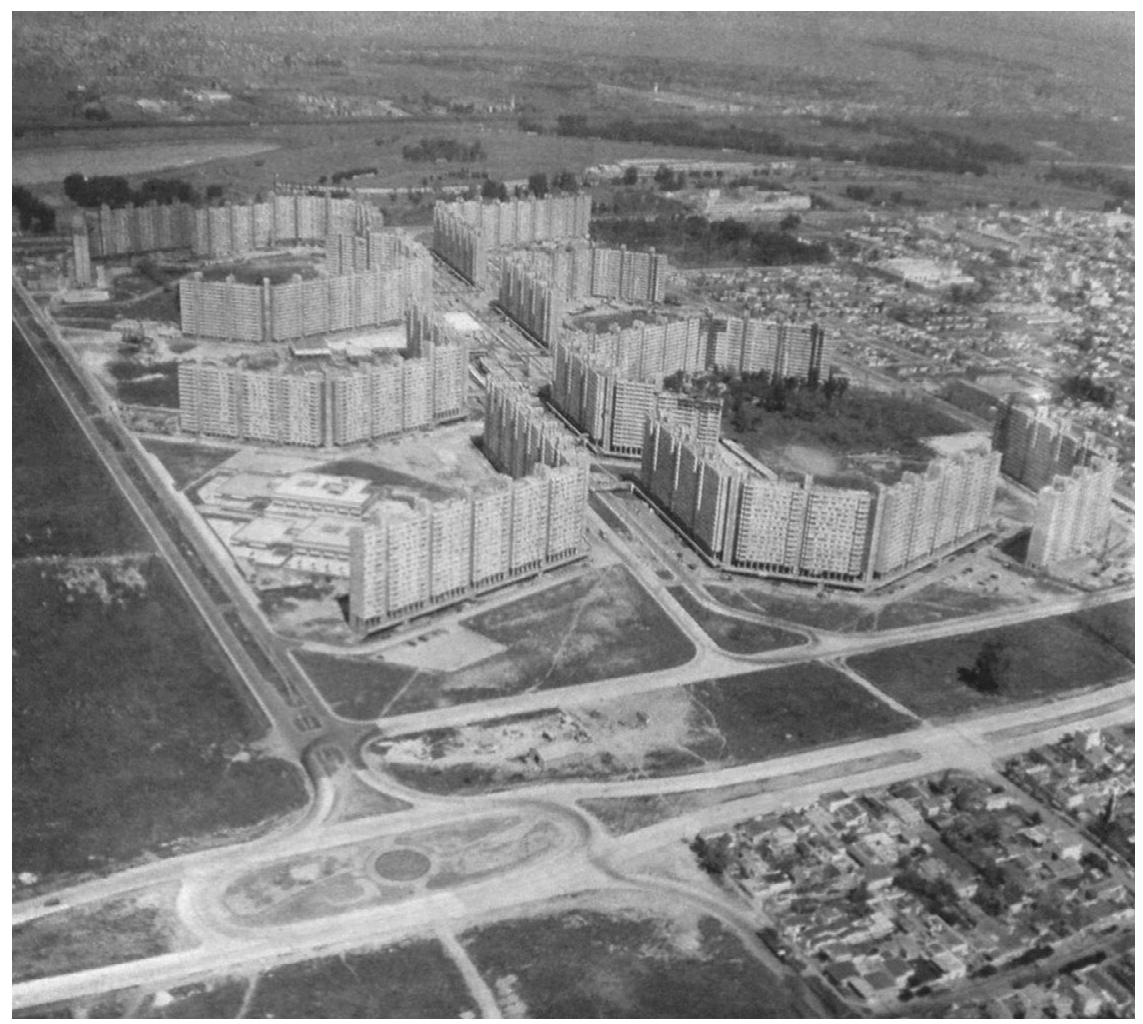

Figure 3: The construction of Villa Lugano I and II, Buenos Aires, $c$. 1971. The innovative urban and architectural design, taken 'from the ideas of the TEAM X, was completely alien to Buenos Aires urban culture. Parque Almirante Brown - Conjunto Urbano Lugano I-II'; Municipalidad de la Ciudad de Buenos Aires, c. 1971.

and social facilities including schools, health posts, day-care centres, a commercial centre, playgrounds, churches and public offices. Envisaging the progressive development of the neighbourhood, the urbanization of the area also implied heavy investment in complex and basic infrastructure like running sewerage and water systems - including the channelling of the Cildañez Creek, connection to gas and electric power and telephone services.

The construction of Villa Lugano I-II proceeded in two stages, consisting of high-density complexes of apartment residences placed in two main strips of 14-storey slab blocks forming a long street corridor. The design was innovative for Buenos Aires urbanism and incorporated the ideas of Team X, a group of young architects that challenged the doctrinaire approach to urbanism of the International Congresses of Modernist 
Architecture (CIAM) in 1953 affirming that the Athens Charter (the key document of CIAM elaborated by Le Corbusier) "Tends to produce "towns" in which vital human associations are inadequately expressed. ${ }^{31}$ In Villa Lugano that influence was in the strict differentiation between vehicular and pedestrian traffic, locating each on different levels to avoid 'mutual interference'. Pedestrian shopping streets, for instance, were situated along an elevated sidewalk at the level of the first floor of the buildings and a system of bridges connected the towers, allowing for the continuity of the urban weave. ${ }^{32}$ The geometric arrangements sought to create a social space that reinforced socialization and circulation, taking advantage of the light, air and open space needed for such a high density of population. The set of drawings and blueprints attached to the loan proposal imagined a warm spatial arrangement in which a white middle class socialized in the areas designed for that purpose.

In Buenos Aires and in Rio de Janeiro, local governments initiated publicly financed low-income housing projects to cope with shortages of houses for poor people and to cope with the growing presence of informal settlements. The construction of these developments was possible due to the arrival of foreign credit, available because of a Cold War scenario that prompted plans of social reform that would contain the threat of social upheaval in the region. The question that remains, however, is about the place of the urban home within the imagination of modernization and development of the 1960s.

\section{Housing as an agent of modernization}

The idea that the new, modern urban environment might 'instill a sense and a need for change ${ }^{\prime 33}$ among the former slum dwellers was widely shared among technocratic elites, policymakers, US representatives, foreign consultants and social scientists. That notion was part of the transnational conversation about the modernization of traditional societies through economic development and the transformation of individuals' daily habits. The urban space was simultaneously the locus of modernity and an agent of modernization; decent housing, more specifically, was the particular site for such transformation. Thus, the provision of adequate housing was not just an urgent social problem for the state but also the place where a new citizen and consumer might be forged.

31 Architects Jaap Bakema, Georges Candilis, Giancarlo De Carlo, Aldo van Eyck, Alison and Peter Smithson and Shadrach Woods were the inner circle of Team X. See Eric Mumford, The CIAM Discourse on Urbanism, 1928-1960 (Cambridge, MA, 2000), 238-57.

32 An idea very much in tune with the work of architects Alison and Peter Smithson for Park Hill, Sheffield, in Britain; Catenazi and Boselli, 'Los arquitectos proyectistas', 15.

33 Comisión Municipal de la Vivienda, Plan piloto para erradicación de las villas de emergencia 56-18. Etapas previas, Plan de prioridades de obras para villas de emergencia; Plan de congelamiento poblacional (Buenos Aires, 1966), II and V. 
The transformation of the squatter dweller into a homeowner, with domestic and collective responsibilities, was a key notion behind the construction of the housing complexes. Chief among these responsibilities was the argument that modern capitalist society demanded of the individual legitimate payment for urban land and public services. The Manual of the Homeowner provided to residents of Vila Kennedy highlighted the responsibility of the homeowner to legalize possession of his homestead: 'This house is yours! Keep it, enlarge it, and embellish it. It's your duty', informed the manual distributed in 1965. 'After legalizing your commitment you made by signing the deed of purchase, pay your monthly fee on time. Remember, your punctuality is worth a home. ${ }^{\prime 34}$ The manual also provided advice on how to perform domestic tasks and satisfy collective duties as a member of the neighbourhood. Accompanying illustrations clearly demarcated the gendered expectation of a male breadwinner signing the deed, paying monthly service fees and maintaining vital records with the local office of the secretary of social services. Women were portrayed performing domestic tasks: a picture of an attractive mother with a broom in one hand and a duster in the other accompanied the legend 'keep your house and surroundings in order and clean'. The caption for a picture of the white mother brushing her daughter's hair mentioned, 'Housewife, mother: Look for the Secretary of the Social Services' office to learn about the preparation of food and care for your children.' Those images may not have represented the racial and gender reality of Vila Kennedy and its residents: the favelado population of Rio de Janeiro was just one third white and most faveladas worked in the formal and informal labour markets in addition to the duties of domestic administration. ${ }^{35}$ Clearly, the Manual of the Homeowner was the expression of a desire that housing should play a role as an agent of social and cultural change.

The notion of homeownership was also present in the booklet To Enter into the Present, distributed to residents in Ciudad General Belgrano on the outskirts of Buenos Aires city. The first page of the booklet showed a set of keys that represented the possibility of entering into the (modern) present through the possession of the house. In the following pages, the manual established a counterpoint between the historical past and the present of the city. The past was the Buenos Aires of the Gran Aldea (the Big Village),

34 Secretaria de Serviços Sociais - COHAB-GB. Manual do propirétario (Rio de Janeiro, 1965), 3-4.

35 The government did not discriminate between whites and non-whites when assigning the housing units. Racial inequality, though, operated in other levels. Janice Perlman has shown that only one third were black, one half white and the rest mulatto. Even though the number of whites may be surprising, it does not equate to racial balance. Blacks, who constituted a third of favela residents, accounted for almost the entire black population of the city. Perlman, The Myth of Marginality, 88. 
the city of the late colonial time. ${ }^{36}$ Back then, the guide explained, the urban life was not comfortable: there was no running water, 'they did not have the ease of merely turning on a faucet to get out the fluids that now we give so little importance' and the children had to retrieve it by carrying containers on their shoulders. A housewife had to get up early in the morning, 'to rub her eyes, and to wash her face with the little remainder of water of the day before [and] light the fire to prepare the breakfast for the man who had to go out to work'. But Buenos Aires became a modern city, a metropolis that incorporated the comforts of modern life. In that present,

the new houses of General Belgrano are an expression of today's Buenos Aires, one of the most modern and beautiful cities in the world. These homes are, then, not only a great architectural work: they provide many families what is necessary for work and rest, and allow them to come into this present and start a new phase of their life. ${ }^{37}$

The juxtaposition of past and the present was not just a contrast between two historical eras. On the contrary, the narrative referred to a different counterpoint, one that opposed traditional to modern societies, a cultural and social condition that could exist simultaneously in the same historical time. Figuratively, the attributes of everyday life in the Gran Aldea depicted in the text did not differ so much from the life of the poor people of Buenos Aires in the 1960s: illegal settlements lacking electric power, running water or even water faucets. This broadly shared image of the 'traditional' character of the inhabitants of the villas was well expressed in 1966 in the first sociological survey conducted in the slums of the Bañado de Flores. The 'Pilot Plan for the Eradication of the Villas de Emergencia 5-6-18' pointed out the role of the government as an agent of change and social integration by providing community development plans as a

temporal and precarious solution to deep needs of the inhabitants of the Villas de Emergencia, that facilitates the motivation of those communities to participate with their own efforts, providing the necessary labour, in the execution of the proposed works in this plan. It is not about palliating needs but about instilling a sense and a need for change... trying to change the mental attitude of the inhabitant of the villas, whose characteristic is a tendency to static quietism, and transform that attitude into a dynamic process of order, organization and development ... the Villa de Emergencia represents more a mental problem than a physical one.

The same Pilot Plan explained 'it is not acceptable that those who live in the Villa de Emergencia, with their minds in the Villas, then go and live in a definitive house without a total change in attitude and abilities' ${ }^{38}$

${ }^{36}$ Lucio Vicente Lopez, a member of the Buenos Aires traditional families of the nineteenth century, coined that name remembering the city of his childhood; Lucio Vicente López, $\mathrm{La}$ Gran Aldea (Buenos Aires, 1884).

37 Comisión Municipal de la Vivienda, Para entrar en el presente, 2-3.

38 Comisión Municipal de la Vivienda, Plan piloto para erradicación de villas de emergencia 5-6-18, II. The emphasis is mine. 
Conceiving poverty as a 'mental' problem may have been a perverse way of blaming the poor for their living conditions, but it was also consistent with a generally optimistic sociology of modernization and structuralfunctionalist anthropology that found that seeds of social maladjustment in prejudicial external conditions might be remedied through selfimprovement. ${ }^{39}$ Educating the poor in community development and selfhelp was a way to transform habits associated with traditional sociability into productive modern living. The house, then, was not just a physical unit but also a whole transformative environment that might encourage a whole new predisposition for urban life. In that sense, the set of keys (the symbol of homeownership) offered in the first page of the manual of the CMV was a symbolic way to cross the threshold to modernity, leaving once and for all the traditional life whose imagined loci were the slums of Buenos Aires.

This image could also be seen in the spatial design behind the different floor plans of Vila Kennedy in Rio. As COHAB-GB reported, the idea of the embryo-house was the key for a successful plan ... which offers basic housing conditions, and in which each homeowner can add and modify his home according to his necessities and possibilities'. ${ }^{40}$ Interestingly enough, the 'embryo-type' assumed that as a people-driven process the design might give the possibility to unleash individual and collective potentials in appropriating and reshaping their housing units according to the families' necessities. In this respect, the plan sought to connect with broader notions of self-help programmes, an idea very much sympathetic with the low-income housing programmes stimulated by USAID and the United Nations for developing countries.

Homeownership and involvement in self-help and community development projects were also part of a Cold War imagination that shaped US foreign aid for the integration and socialization of the poor inhabitant into the urban setting. In 1959, the US Council on Foreign Economic Policy (CFEP), the agency created by President Eisenhower in 1954 to co-ordinate foreign economic policy, tried to obtain support from private investors to channel funds for housing in Latin America. 'Private home ownership is basic capitalism', affirmed the documents. 'If the free enterprise capitalistic system is to be propagated and strengthened elsewhere in the world, there is no greater appeal to the hearts and minds of men than to espouse the cause of owning one's home.' Proprietorship might generate dignity and pride, according to, the CFEP, that in turn would be politically positive, as it would generate a rejection of the communist ideology and its concepts of state ownership and elimination of private property. 'As a further bulwark

39 Scholars such as Oscar Lewis and his 'culture of poverty' or Robert Redfield's ideas on the urban-folk continuum were very much influential in the scholarship on urban poverty in the Americas in the 1960s. See for instance, Perlman, The Myth of Marginality, 91-132.

40 COHAB-GB, Relatório Geral - 1963/1965 (Rio de Janeiro, 1965), 104. 
against communism, expanded private home ownership will help to build a substantial citizenry and more stable political climate. ${ }^{41}$

More succinctly, the US ambassador to Brazil, Lincoln Gordon, explained the crucial role of housing and international co-operation in terms that had become the conventional understanding in the Cold War period when he signed off on a new release of funding for Rio's housing complexes in April 1965. He linked 'decent housing' with the 'full development' of the Brazilian economy and society and pointed out that the true friendship of the United States for the people of Brazil can be only realized by our financial assistance being used as an impetus to their own efforts to solve their problems'. ${ }^{42}$ Months later, L. Albert Wilson, USAID consultant working with the IDB, used similar terms in his report on the villas of the Parque Almirante Brown, 'It is my deepest hope', wrote Wilson,

that this information and analysis may contribute to a fresh, positive and creative understanding between the people of Gran Buenos Aires and the residents of the Villas, resulting in a re-location and community development project which will be only the dawn of an era of accelerating social and economic progress and an exemplary model for the other cities of this hemisphere of ours. ${ }^{43}$

\section{Conclusions}

'We are now in the present', exclaimed the Users' Guide for the inhabitants of General Belgrano. 'The houses will gradually take their own tone, style and personality. That little picture and that curtain will give the first and last name to these households, which will now become home. Henceforth, the life of the families, of every man, of every woman and every child, and the entire neighbourhood will give meaning to this work. ${ }^{44}$ To become the owner of a house in the recently built low-income housing development was part of becoming a member of a modern urbs. Being in the 'present' implied the abandonment of those habits, costumes and mental predisposition related to traditional, rural environments; especially for those who had been living in the favelas of Rio and the villas miserias of Buenos Aires.

In both Buenos Aires and Rio de Janeiro a similar language can be found in the framing of municipal and federal actions towards the poor population. Affordable housing development, self-help and community development plans were framed within optimistic expectations of

41 In Zoumaras, 'Containing Castro', 176.

42 Draft of speech of Ambassador Lincoln Gordon when signing of $\mathrm{Cr} \$ 4$ billion release to the Guanabara Housing Project on 28 Apr. 1965, corrected by US Information Agency, National Housing Bank, Low Cost Housing - Guanabara FY 66, Brazil Subj/Proj 56-73, Acc \# 75-0162, box 25, RG 286, US National Archives and Records Administrations.

${ }^{43}$ L. Albert Wilson, letter to the Honourable Francisco Rabanal, mayor, city of Buenos Aires, included in Voice of the Villas.

${ }^{44}$ Comisión Municipal de la Vivienda, Para entrar en el presente, 23. 
modernizing people's habits and attitudes by providing new spatial settings.

The values related to the modernization and developments of the urban dwellers were very much in tune with US foreign ideals in the Cold War era. As assistant secretary of state for inter-American affairs, Thomas C. Mann, commented,

in all this, we are partners in an historic effort under the Alliance for Progress, an effort which joins progressive and forward-looking people of the hemisphere to one overriding purpose and one purpose only: the improvement of the condition of human life in Latin America. We seek no political or economic advantage. We have no territorial ambition. We do not seek to impose our will on others. We seek only to join hands in the reform and development of this, our hemisphere, so that each nation can take its rightful place in the community of nations - free, democratic, self-confident and able to provide for its own people the jobs, schools and decent life to which all men in this century are entitled. ${ }^{45}$

Thus, housing in the Americas could be also understood as one of the many scenarios in which Cold War rationale and geopolitics unfolded.

Still, this modernizing imagination was not an ideology imposed externally on Latin America. On the contrary, those in charge of explaining the structural economic and social changes of the region as well as those responsible for promoting development through the administration of the state apparatus shared the idea of the city as an agent of transformation of the individual. That common language was transnationally built through the constitution of networks and the encounter of actors across national and international borders in conferences, entrepreneurial meetings or in multinational organizations like the Organization of American States or the United Nations.

Yet, while newly built housing complexes sought to eradicate poverty and develop modern habits, Latin American cities came to be marked by extreme income disparities. In reality, the striking modernist architecture of Villa Lugano I-II and the modest respectability of the single-family homes built in Ciudad General Belgrano failed to provide for a varied and textured landscape. In Villa Lugano, a creeping authoritarianism, reinforced by weak official support for the original plan, became part of an urban landscape whose previous spatial arrangement had been organized

45 Remarks by the Honourable Thomas C. Mann, assistant secretary of state for interAmerican affairs, before the Houston Council on World Affairs, Houston, Texas, Wednesday 23 Sep. 1964, The Alliance for Progress: A Challenge and an Opportunity, in Juracy Magalhaes' collection: J.M. pi Mann, T: 64.09.23, located in CPDOC. President Johnson appointed Thomas Mann as US co-ordinator of the Alliance for Progress in December 1963. The Mann Doctrine represented a return to the Atlantic Charter (1941) but in the context of the Cold War it meant that Latin American countries were considered according to what they did to further the interests of the United States in fighting communism and Castrism. 
around the republican ideals of the grid and plaza. ${ }^{46}$ With construction costs kept to a minimum, individual housing units in Ciudad General Belgrano failed to create the material conditions of an aspirant middleclass consumerism. In Rio, even after the construction of Vila Kennedy and Vila Aliança as low-income housing developments, and the creation of hundreds of new homeowners, the residents were still stigmatized as favelados. The expected development of the area as an industrial district failed to materialize and the lack of means of transportation reinforced a sense of spatial isolation.

By the end of the 1960s, the Alliance for Progress had shown its weaknesses. Economically, Latin American countries did not grow as expected; on the contrary, poverty increased. Authoritarian military regimes replaced democratic governments in Brazil from 1964 to 1984, and from 1966 to 1973 and 1976 to 1983 in Argentina. That meant that social reform was no longer an important point in the foreign policy agenda of the United States, since military regimes were more efficient in containing social demands. The cycles of political instability and economic fluctuation associated with the faltering politics of populism hampered numerous projects of housing reform, and the rise of the national security state placed tremendous ideological limits on an open politics of urban development and sociability. The urban residential dwelling in Buenos Aires and Rio at the end of the era of modernization nevertheless failed to be the rationalized, commodified and democratized space that early post-war planners had envisioned. Wondrous apartment buildings and planned worker housing developments stood alongside new chaotic land invasions and squatter settlements.

Ultimately, the planning and building of the modern residence did not solve the problem of underdevelopment. Rather, I argue, housing itself built new forms of informality and marginality. In other words, at the historical juncture of populism, inter-American development aid, and the Cold War in the Americas, the urbanists' plans and hopes for modernity through housing may have been partially fulfilled, but a poverty of housing became a thoroughly modern part of the Latin American urban landscape.

${ }^{46}$ Adrián Gorelik has argued that the urban grid in Buenos Aires became a cultural artifact linked with nineteenth-century republican ideals of democratizing the urban space; in $\mathrm{La}$ grilla y el parque: espacio público y cultura urbana en Buenos Aires, 1887-1936 (Buenos Aires, 1998). 